\title{
Evaluation of the Antioxidant Effects of Postbiotics and Paraprobiotics in Lactic Acid Bacteria Isolated from Traditional Fermented Sausages
}

\author{
Betül Aydın ${ }^{1 *}$, Tuğçe Çiydem² ${ }^{2}$ Esra Kaya ${ }^{3}$, Leyla Açık ${ }^{4}$ \\ $\mathbf{1}^{*}$ Gazi University, Faculty of Science, Departmant of Biology, Ankara, Turkey, (ORCID: 0000-0002-9092-1350), barslan@gazi.edu.tr \\ ${ }^{2}$ Gazi University, Faculty of Science, Departmant of Biology, Ankara, Turkey, (ORCID: 0000-0001-7430-1891), ciydemtugce@gmail.com \\ ${ }^{3}$ Gazi University, Faculty of Science, Departmant of Biology, Ankara, Turkey, (ORCID: 0000-0001-5449-7794), esrakaya1715@gmail.com \\ ${ }^{4}$ Gazi University, Faculty of Science, Departmant of Biology, Ankara, Turkey, (ORCID: 0000-0002-3672-8429), leylaacik@gazi.edu.tr
}

(1st International Conference on Applied Engineering and Natural Sciences ICAENS 2021, November 1-3, 2021)

(DOI: 10.31590/ejosat.1011409)

\begin{abstract}
ATIF/REFERENCE: Aydın, B., Çiydem, T., Kaya, E. \& Açık, L. (2021). Evaluation of the Antioxidant Effects of Postbiotics and Paraprobiotics in Lactic Acid Bacteria Isolated from Traditional Fermented Sausages. European Journal of Science and Technology, (28), 849-852.
\end{abstract}

\begin{abstract}
Recent studies in the field of probiotic biotechnology have shown that some non-living microorganisms or the metabolites they produce have at least as valuable biological activities as probiotic bacteria. Paraprobiotics are described as non-viable microbial cells that confer a benefit to the human or animal when administered in adequate amounts. Bioactive soluble metabolic byproducts produced by live probiotic microorganisms that impart some physiological benefit to the host are referred to as postbiotics. Live probiotic bacteria have been used for many years to strengthen the antioxidant defense system against oxidative stress that causes many diseases. The antioxidant activity of postbiotics and paraprobiotics in lactic acid bacteria isolated from twelve different hand-made fermented sausages was assessed using the DPPH radical scavenging assay in this research. It was determined that the free radical scavenging effect of postbiotics used in the study was between $5.65 \%$ and $76.04 \%$, and the effect of paraprobiotics varied between $5.90 \%$ and $18.07 \%$. According to the findings, antioxidant capacity of the postbiotics and paraprobiotics are strain-dependent and the postbiotics have higher antioxidant activity than the paraprobiotics.
\end{abstract}

Keywords: Lactic acid bacteria, postbiotics, paraprobiotics, antioxidant activity, fermented sausages.

\section{Geleneksel Fermente Sucuklardan İzole Edilen Laktik Asit Bakterilerindeki Postbiyotik ve Paraprobiyotiklerin Antioksidan Etkilerinin Değerlendirilmesi}

$\ddot{O} \mathbf{z}$

Probiyotik biyoteknolojisi alanındaki son çalışmalar, bazı cansız mikroorganizmaların veya ürettikleri metabolitlerin en az probiyotik bakteriler kadar değerli biyolojik aktivitelere sahip olduğunu göstermiştir. Paraprobiyotikler, yeterli miktarlarda uygulandığında insan veya hayvana fayda sağlayan canlı olmayan mikrobiyal hücreler olarak tanımlanmaktadır. Canlı probiyotik mikroorganizmalar tarafindan üretilen ve konakçıya bazı fizyolojik faydalar sağlayan biyoaktif çözünür metabolik yan ürünlere ise postbiyotikler denilmektedir. Canlı probiyotik bakteriler, birçok hastalığa neden olan oksidatif strese karşı antioksidan savunma sistemini güçlendirmek için uzun yıllardır kullanılmaktadır. Bu çalışlmada on iki farklı el yapımı fermente sucuk örneğinden izole edilen laktik asit bakterilerindeki postbiyotiklerin ve paraprobiyotiklerin antioksidan aktivitesi DPPH radikal süpürücü etki yöntemi kullanılarak değerlendirilmiştir. Çalışmada kullanılan postbiyotiklerin serbest radikal süpürücü etkisinin $\% 5,65$ ile \%76,04 arasında, paraprobiyotiklerin etkisinin ise $\% 5,90$ ile $\% 18,07$ arasında değiştiği belirlenmiştir. Elde edilen bulgulara göre, postbiyotiklerin ve paraprobiyotiklerin antioksidan kapasitesinin suşa bağımlı olduğu ve postbiyotiklerin paraprobiyotiklere göre daha yüksek antioksidan aktiviteye sahip olduğu tespit edilmiştir.

Anahtar Kelimeler: Laktik asit bakterileri, postbiyotikler, paraprobiyotikler, antioksidan aktivite, fermente sucuk. 


\section{Introduction}

Functional foods can be defined as items that are specifically designed to meet any given requirement in terms of functionality, nutrition, convenience, and medicinal characteristics [1]. The use of probiotic microorganisms as "food additives" has experienced tremendous growth in the functional food industry in recent years. Probiotics, according to the World Health Organization and the Food and Agriculture Organization, are living non-pathogenic microorganisms that have been shown to have well-documented beneficial health effects when given in the right doses in the prevention and treatment of a variety of diseases [2]. Probiotic bacteria can contribute to the balance of the host's gut microbiota, alter immunological response, and act as health promoters in a variety of ways [3].

Fermented meat have been consumed by humans for thousands of years, and some of these items are still part of our daily meals. Lactic acid bacteria (LAB) are primarily responsible for the fermentation of meat raw materials [4]. It is known that many strains of lactic acid bacteria have probiotic activity [5].

New terms like paraprobiotic and postbiotic have evolved, implying that bacterial viability isn't required for health benefits, potentially creating new opportunities in the field of functional foods. Paraprobiotics are non-viable microbial cells or raw cellular extracts that provide a benefit to the human or animal consumer when given in sufficient proportions. Bacterial metabolites and byproducts produced by living probiotic microorganisms or released after cell rupture that provide any physiological advantage to the host are referred to as postbiotics [6]. In vitro and in vivo investigations have revealed that several postbiotics and paraprobiotics have anti-inflammatory, immunomodulatory, anti-proliferative, antioxidant, and antibacterial properties [7].

The aim of this study is to evaluate the antioxidant activitiy of postbiotics and paraprobiotics of LAB isolated from fermented sausages.

\section{Material and Method}

\subsection{Isolation of $\mathbf{L A B}$}

12 different fermented sausages were bought from local markets in Ankara, Turkey using traditional techniques without the use of starter cultures. Each of these samples (10 g) was separately blended and added to $900 \mathrm{~mL}$ of sterile buffered peptone water (Merck, Germany), and homogenized. The same diluent was used to make serial 10 -fold dilutions. The surface spreading technique was used to apply $0.1 \mathrm{~mL}$ of the adequately diluted sample to the surface of the de Man, Rogosa Sharpe Agar media (MRS, Merck). The plates were incubated aerobically at $37^{\circ} \mathrm{C}$ for $48 \mathrm{~h}$. After incubation, colonies were randomly picked from plates based on their morphological traits. Gram staining and catalase production were used to classify the purified isolates. The isolates of catalase negative, Gram-positive rods or cocci were presumed to be LAB. Typical LAB isolates were identified with MALDI-TOF MS Biotyper (Bruker Daltonics, Germany) at species level and stored at $-80^{\circ} \mathrm{C}$ in MRS broth with glycerol.

\subsection{Preparation of Postbiotics and Paraprobiotics}

All of the isolates were grown in MRS broth for $24 \mathrm{~h}$ at 37 ${ }^{\circ} \mathrm{C}$. The cells were separated by centrifugation at $10,000 \times \mathrm{g}$ for e-ISSN: 2148-2683
$10 \mathrm{~min}$. The supernatant was filtered through $0.22 \mu \mathrm{m}$ pore sized membrane syringe filter (Millipore, USA). The harvested cell-free supernatant (postbiotic) was kept at $4^{\circ} \mathrm{C}$ until used in antioxidant activity assay.

After centrifugation, cell pellets were used for preparing the paraprobiotics. The cell pellet was washed with distilled water and suspended in the same solvent, and then the cells were killed by sonication for $5 \mathrm{~min}$. [8]. This solution was used as paraprobiotics.

\subsection{Antioxidant Activities of Postbiotics and Paraprobiotics}

The free radical scavenging potential of the samples was evaluated by 1,1-Diphenyl-2-picrylhydrazyl (DPPH) scavenging assay [9]. $0.5 \mathrm{~mL}$ of postbiotic or paraprobiotic sample mixed with a freshly prepared methanolic solution of DPPH radical $(0.1$ $\mathrm{mM}$ ). Following the incubation at room temperature in the dark for $30 \mathrm{~min}$, absorbance was read by a spectrophotometer (Shimadzu UV-1800, Japan) at $517 \mathrm{~nm}$ against a blank. The percentage of DPPH radical scavenging effect was calculated using the equation below:

DPPH scavenging activity (inhibition $\%)=[($ AcontrolAsample)/Acontrol]x100, where Acontrol is the absorbance of the control and Asample is the absorbance of the reaction mixture.

\section{Results and Discussion}

In the present study, the antioxidant ability of the postbiotic and paraprobiotics was evaluated by using the DPPH radical scavenging activity method and the inhibition percentages of the samples are given in Table 1. The inhibition percentages of the postbiotic samples were between $5.65 \%$ and $76.04 \%$; paraprobiotic samples were found to be between $5.90 \%$ and $18.07 \%$. It was determined that the antioxidant activity of postbiotic samples was higher than parabiotic samples of the same strain. The highest antioxidant activity in the postbiotic samples was detected in Enterococcus faecium ETE12 strain (76.04\%). Therefore, the highest antioxidant activity among paraprobiotic samples was observed in Enterococcus faecium ETE10 strain $(18.07 \%)$.

Peroxidation is caused by the critical process of oxidative metabolism in cells, which produces reactive oxygen species and free radicals that cause oxidative damage [10]. Antioxidants from natural sources have been used to mitigate the effects of oxidative stress and reactive oxygen species. Probiotics have long been known to offer a variety of health benefits, and studies have shown that strain-specific probiotics can have antioxidant activity and prevent oxidative damage when consumed alone or in meals [11].

Synthetic antioxidants are frequently employed in the creation and maintenance of meals, however they may cause a variety of health problems. As a result, finding and developing natural antioxidants is critical for protecting the human body from oxidative stress and slowing the progression of many diseases. There are many studies on the use of probiotic lactic acid bacteria isolated from different fermented foods as a natural source of antioxidants [12, 13, 14]. Also, the antioxidant properties of postbiotic and paraprobiotic samples obtained from various bacterial strains were evaluated separately in some studies $[15$, $16,17]$. However, there is no study in the literature comparing the antioxidant activity of postbiotic and paraprobiotics in the same 
bacterial strain. In this study, it was aimed to evaluate the antioxidant activity of postbiotic and paraprobiotics of lactic acid bacteria isolated from fermented sausages. When the data obtained were evaluated, it was determined that the antioxidant activity of postbiotic and paraprobiotics was strain-dependent. It is known that these differences in the antioxidant activity of postbiotics and paraprobiotics vary depending on the antioxidant enzymes, metabolites and metal ion chelators contained in the postbiotics and paraprobiotics [16]. Therefore, the properties of the mentioned antioxidant molecules may differ in other strains of the same genus or species [6].

The results show that the obtained postbiotics have higher antioxidant capacity than paraprobiotics. While the cells are growing in culture, they secrete the metabolites that they form outside the cell during the incubation period. For this reason, it is expected that the postbiotics in the culture medium are more than the metabolites in the cell. The difference between the antioxidant activity of postbiotics and paraprobiotics is thought to be due to this situation.

Previous studies have shown that postbiotics have several pharmacodynamic features that are superior to live bacteria [18, $19,20]$. In addition to all these, postbiotics are recommended to be used instead of live bacteria in foods due to their advantages such as being easier to transport and storing, and the less possibility of transferring antibiotic resistance genes [21, 22]. In the current study, it has been shown that postbiotics are more effective than paraprobiotics in terms of antioxidant capacity in the bacterial strains studied.

Table 1. DPPH scavenging activities of postbiotics and paraprobiotics (inhibition\%)

\begin{tabular}{|c|c|c|}
\hline Strain & $\begin{array}{c}\text { Postbiotic } \\
\text { samples }\end{array}$ & $\begin{array}{c}\text { Paraprobiotic } \\
\text { samples }\end{array}$ \\
\hline $\begin{array}{c}\text { Leuconostoc } \\
\text { mesenteroides } \text { ETE1 }\end{array}$ & $49.88 \pm 0$ & $10.27 \pm 1.47$ \\
\hline $\begin{array}{c}\text { Leuconostoc } \\
\text { mesenteroides } \text { ETE2 }\end{array}$ & $41.40 \pm 0.52$ & $9.90 \pm 0.12$ \\
\hline $\begin{array}{c}\text { Weissella cibaria } \\
\text { ETE3 }\end{array}$ & $5.65 \pm 2.08$ & $5.90 \pm 0.72$ \\
\hline $\begin{array}{c}\text { Lactococcus lactis } \\
\text { ETE4 }\end{array}$ & $70.52 \pm 2.08$ & $12.79 \pm 1.08$ \\
\hline $\begin{array}{c}\text { Enterococcus faecalis } \\
\text { ETE5 }\end{array}$ & $68.06 \pm 0.43$ & $12.71 \pm 0.48$ \\
\hline $\begin{array}{c}\text { Leuconostoc } \\
\text { mesenteroides } \text { ETE6 }\end{array}$ & $69.41 \pm 0.52$ & $11.94 \pm 0.36$ \\
\hline $\begin{array}{c}\text { Enterococcus hirae } \\
\text { ETE7 }\end{array}$ & $71.99 \pm 1.28$ & $17.30 \pm 0.24$ \\
\hline $\begin{array}{c}\text { Enterococcus faecium } \\
\text { ETE10 }\end{array}$ & $70.15 \pm 1.56$ & $18.07 \pm 1.32$ \\
\hline $\begin{array}{c}\text { Enterococcus faecalis } \\
\text { ETE11 }\end{array}$ & $66.09 \pm 1.04$ & $16.36 \pm 1.32$ \\
\hline $\begin{array}{c}\text { Enterococcus faecium } \\
\text { ETE12 }\end{array}$ & $76.04 \pm 1.56$ & $12.20 \pm 0.72$ \\
\hline
\end{tabular}

\section{Conclusions and Recommendations}

Paraprobiotics and postbiotics, show a lot of promise as antioxidant agents, as well as other health benefits. These properties lead to the emergence of new pharmaceutical treatments for various diseases associated with oxidative stress and are safer alternatives to live microorganisms. However, further research is needed to confirm the benefits of paraprobiotics and postbiotics.

\section{Acknowledge}

We would like to thank Dr. Aysun Uysal from Hatay Mustafa Kemal University Centre for Implementation and Research of Plant Health Clinic, who performed MALDI-TOF analyzes for the identification of bacteria.

\section{References}

[1] Granato, D., Barba, F. J., Bursać Kovačević, D., Lorenzo, J. M., Cruz, A. G., \& Putnik, P. (2020). Functional foods: Product development, technological trends, efficacy testing, and safety. Annual Review of Food Science and Technology, 11, 93-118.

[2] Food and Agricultural Organization of the United Nations and World Health Organization. (2021). Health and nutritional properties of probiotics in food including powder milk with live lactic acid bacteria. World Health Organization [Online]. Available: http://who.int/foodsafety/fs_management/en/ probiotic_guidelines.pdf. 2002.

[3] Trush, E. A., Poluektova, E. A., Beniashvilli, A. G., Shifrin, O. S., Poluektov, Y. M., \& Ivashkin, V. T. (2020). The evolution of human probiotics: challenges and prospects. Probiotics and Antimicrobial Proteins, 12(4), 1291-1299.

[4] Ojha, K. S., Kerry, J. P., Duffy, G., Beresford, T., \& Tiwari, B. K. (2015). Technological advances for enhancing quality and safety of fermented meat products. Trends in Food Science \& Technology, 44(1), 105-116.

[5] Quinto, E. J., Jiménez, P., Caro, I., Tejero, J., Mateo, J., \& Girbés, T. (2014). Probiotic lactic acid bacteria: a review. Food and Nutrition Sciences, 5(18), 1765.

[6] Barros, C. P., Guimarães, J. T., Esmerino, E. A., Duarte, M. C. K., Silva, M. C., Silva, R., ... \& Cruz, A. G. (2020). Paraprobiotics and postbiotics: concepts and potential applications in dairy products. Current Opinion in Food Science, 32, 1-8.

[7] Cuevas-González, P. F., Liceaga, A. M., \& Aguilar-Toalá, J. E. (2020). Postbiotics and paraprobiotics: From concepts to applications. Food Research International, 109502.

[8] Pieniz, S., Andreazza, R., Anghinoni, T., Camargo, F., \& Brandelli, A. (2014). Probiotic potential, antimicrobial and antioxidant activities of Enterococcus durans strain LAB18s. Food Control, 37, 251-256.

[9] Braca, A., De Tommasi, N., Di Bari, L., Pizza, C., Politi, M., \& Morelli, I. (2001). Antioxidant principles from bauhinia t arapotensis. Journal of Natural Products, 64(7), 892-895.

[10] Schogor, A. L. B., Palin, M. F., dos Santos, G. T., Benchaar, C., Lacasse, P., \& Petit, H. V. (2013). Mammary gene expression and activity of antioxidant enzymes and oxidative indicators in the blood, milk, mammary tissue and ruminal fluid of dairy cows fed flax meal. British Journal of Nutrition, 110(10), 1743-1750.

[11] Lin, M. Y., \& Yen, C. L. (1999). Antioxidative ability of lactic acid bacteria. Journal of Agricultural and Food Chemistry, 47(4), 1460-1466.

[12] Afify, A. E. M. M., Romeilah, R. M., Sultan, S. I., \& Hussein, M. M. (2012). Antioxidant activity and biological evaluations of probiotic bacteria strains. International Journal of Academic Research, 4(6).

[13] Amaretti, A., Di Nunzio, M., Pompei, A., Raimondi, S., Rossi, M., \& Bordoni, A. (2013). Antioxidant properties of 
potentially probiotic bacteria: in vitro and in vivo activities. Applied Microbiology and Biotechnology, 97(2), 809-817.

[14] Zhang, S., Liu, L., Su, Y., Li, H., Sun, Q., Liang, X., \& Lv, J. (2011). Antioxidative activity of lactic acid bacteria in yogurt. African Journal of Microbiology Research, 5(29), 5194-5201.

[15] Ou, C., Ko, J., \& Lin, M. (2006). Antioxidative effects of intracellular extracts of yogurt bacteria on lipid peroxidation and intestine 407 cells. Journal of Food and Drug analysis, 14(3), 304-310.

[16] Chang, H. M., Foo, H. L., Loh, T. C., Lim, E. T. C., \& Mutalib, N. E. A. (2020). Comparative Studies of Inhibitory and Antioxidant Activities, and Organic Acids Compositions of Postbiotics Produced by Probiotic Lactiplantibacillus plantarum Strains Isolated From Malaysian Foods. Frontiers in Veterinary Science, 7.

[17] Martorell, P., Alvarez, B., Llopis, S., Navarro, V., Ortiz, P., Gonzalez, N., ... \& Tortajada, M. (2021). Heat-Treated Bifidobacterium longum CECT-7347: A Whole-Cell Postbiotic with Antioxidant, Anti-Inflammatory, and GutBarrier Protection Properties. Antioxidants, 10(4), 536.

[18] Jang, H. J., Song, M. W., Lee, N. K., \& Paik, H. D. (2018). Antioxidant effects of live and heat-killed probiotic Lactobacillus plantarum Ln1 isolated from kimchi. Journal of Food Science and Technology, 55(8), 3174-3180.

[19] Hsieh, F. C., Lan, C. C. E., Huang, T. Y., Chen, K. W., Chai, C. Y., Chen, W. T., ... \& Wu, C. S. (2016). Heat-killed and live Lactobacillus reuteri GMNL-263 exhibit similar effects on improving metabolic functions in high-fat diet-induced obese rats. Food \& Function, 7(5), 2374-2388.

[20] Thakur, B. K., Saha, P., Banik, G., Saha, D. R., Grover, S., Batish, V. K., \& Das, S. (2016). Live and heat-killed probiotic Lactobacillus casei Lbs2 protects from experimental colitis through Toll-like receptor 2-dependent induction of T-regulatory response. International Immunopharmacology, 36, 39-50.

[21] Piqué, N., Berlanga, M., \& Miñana-Galbis, D. (2019). Health benefits of heat-killed (Tyndallized) probiotics: An overview. International Journal of Molecular Sciences, 20(10), 2534.

[22] Nataraj, B. H., Ali, S. A., Behare, P. V., \& Yadav, H. (2020). Postbiotics-parabiotics: the new horizons in microbial biotherapy and functional foods. Microbial Cell Factories, 19(1), 1-22. 